\title{
A Comparative Analysis of Economic Performance in Two Eras: Democratic Era (FY 89 - FY99) \& Military Rule (FY00 - FY05)
}

\author{
Vishnu Parmar* and S. M. Shafi Azam** \\ SZABIST \\ Karachi, Pakistan
}

\begin{abstract}
Throughout Pakistan's 58 year history two forms of government, namely, military and democratic rule have been imposed on the country. Although the economic and social performance of the two types of government has been documented extensively in terms of qualitative research methodology, no comprehensive quantitative model utilizing inferential statistical techniques to assess their performance has been published in current literature so far. This study attempts to develop a multi-dimensional framework of analysis to establish the statistical significance of key economic and social indicators using sample data between FY1989-FY2005. The major objective of the paper is to analyze the group means of 28 economic variables, using inferential statistical techniques, between FY1989-FY1999 and FY2000-FY2005; each period representing different types of governments.
\end{abstract}

The results obtained from the quantitative analysis displays substantial statistical significance. 16 out of 28 macroeconomic variables show no significant difference in the group means of two eras and there is extremely strong evidence to support the null hypotheses formulated. Some of the main variables amongst them are: GDP growth rate, growth of investment, growth of large and small scale manufacturing, export performance, investment in health and education, balance of trade, and debt servicing.

\section{INTRODUCTION}

Pakistan's economic history since its birth has shown mixed results. The different types of governments which have ruled the nation have influenced its macroeconomic performance. The development during president Ayub Khan has been documented to be the best era in the history of Pakistan. During this period the GDP growth rate averaged 6.8\%. Figure 1 illustrates the history from 1950-2005[1].

According to the Economic Survey of Pakistan (2005), the economy gathered greater momentum during fiscal year FY2004-05 as Pakistan's real GDP grew by $8.4 \%$ against $6.4 \%$ in FY2003-04. All major macroeconomic indicators exhibited improvement compared to previous years.

*MS Student, SZABIST

** Consultant, World Bank

Journal of Independent Studies and Research (JISR)

Volume 4, Number 2, July 2006
The sharp pick up in growth was mainly supported by an exceptional performance in large-scale manufacturing, impressive recovery in agriculture, and strong growth in services sector. Large Scale Manufacturing grew by 15.4 percent against the target 12.2 percent. Agriculture posted a growth of $7.5 \%$

against the target of $4.0 \%$.The services sector registered an equally strong growth of $7.9 \%$ [2].
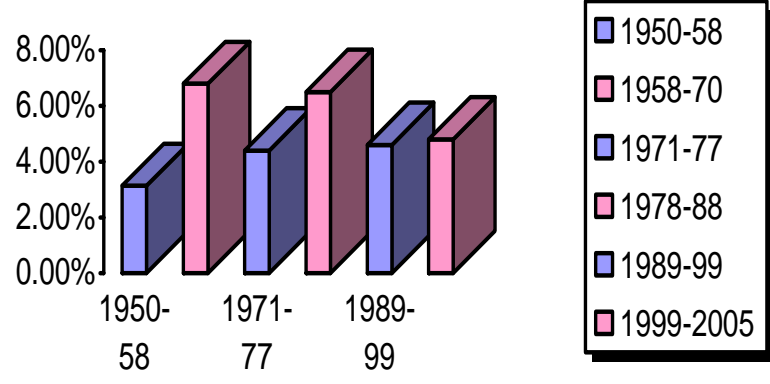

Figure 1: Average GDP Growth Rate

Although Pakistan's economic performance improved further in FY2005-06 as illustrated by the major macroeconomic indicators, shortages of essential food items, high oil prices, and inflation increased sharply. The fiscal deficit also increased, and the current account of the balance of payments turned into deficit after three years of surplus. Lastly, trade deficit exceeded US \$6 billion, which is highest in decades.

Pakistan army has governed the country overtly and covertly during most of its 58 years history. The seeds of democracy have never been sown due to the continuous political interventions by armed forces. During the period 1988-99, there were seven different governments and two elected prime ministers who were both elected twice. This was a highly uncertain period and no government completed their constitutional tenure. During the last three years, Pakistan's economy has reached a stage where it enjoys high growth, huge foreign exchange reserves, increasing industrial production, and robust capital markets. While macroeconomic stability have been achieved to certain degree, the economy seems still to be at the take-off stage. Pakistan is still faced with challenges like boosting foreign and local new investment, eliminating 
public sector deficits, creating new infrastructure, expanding social sector development, and finally reducing poverty, inflation and unemployment. The sustainability of future growth is questioned given the structural weaknesses in governance and the socioeconomic system as a whole.

\subsection{Problem Statement}

Political instability in Pakistan has divided its political economic structure into two different types of governance: (i) democratic government and (ii) outright military rule. Although overall economic performance during the military regimes have exhibited better results when measured nominally by overall key macroeconomic yearly indicators, the statistics true significance has never been studied inferentially over two different time periods in order to formulate appropriate policy measures for sustainable growth and prosperity.

\subsection{Hypotheses}

Ho: There is no significant meaningful difference in the economic performance during the democratic era and the military regime.

H1: There is a significant difference in the economic performance during the democratic era and the military regime.

Ho: There is no significant meaningful difference in the quality of life during the two eras as measured by the social indicators.

H1: There is a significant meaningful difference in the quality of life during the two eras as measured by the social indicators.

Further, twenty-eight sub hypotheses based on selected 28 macroeconomic and social indicators were developed.

\section{REVIEW OF LITERATURE}

There has been a lot of work done to study and assess the overall economic performance of Pakistan using descriptive statistics, but there is no study to assess it using inferential statistics. Most of the studies to evaluate the economic industrial performance are qualitative in nature utilizing descriptive statistics. In the recent past, two studies have been published which compare macroeconomic indicators. These studies are based upon the comparison of one year with another, while this paper compares the group means of two different periods. Moreover, dozen of articles, comments, and studies have been published in articles and journals highlighting the remarkable turnaround in Pakistan's economy. Most of them are concluding that the country is finally on the right track which will lead it to further stability and sound economic growth.
Mr. Faisal Cheema attempted to study fifteen macroeconomic indicators over a period 1997-2003. His analysis was simple to the extent that he just compared the indicators during 2003 with that of 1997.

He sums up his conclusions as "Pakistan has made considerable progress in achieving macroeconomic stability. There has been a considerable improvement in all the macroeconomic indicators. However, the economy

of Pakistan is still at the take-off stage and faces many daunting challenges. Poverty and unemployment are still high, posing serious challenges to the policy makers in Islamabad” [3].

Table 1: Changes in Key Macroeconomic Indicators

Source: Ashfaque Hasan Khan, "Economic Performance during 1999-2002", Ministry of Finance, Government of Pakistan, http://www.finance.gov.pk/summary/99_2002.pdf, 23. See also State Bank of Pakistan, Economic Data, http://www.sbp.org.pk/ecodata/eimports.pdf

\begin{tabular}{|c|c|c|c|}
\hline Indicators & $\begin{array}{l}\text { October } \\
1999\end{array}$ & June 2003 & Change \\
\hline $\begin{array}{l}\text { GDP } \quad \text { Growth } \\
\text { Rate }\end{array}$ & $4.2 \%$ & $5.1 \%$ & Pos \\
\hline Inflation & $5.7 \%$ & $3.3 \%$ & Pos \\
\hline $\begin{array}{l}\text { Fiscal } \\
\text { Deficit/GDP }\end{array}$ & $-6.1 \%$ & $-4.0 \%$ & Pos \\
\hline $\begin{array}{l}\text { Current } \\
\text { Acc.t/GDP }\end{array}$ & $-3.2 \%$ & $+7.1 \%$ & Pos \\
\hline $\begin{array}{l}\text { Domestic } \\
\text { Debt/GDP }\end{array}$ & $52.0 \%$ & $43.4 \%$ & Pos \\
\hline External Debt & $\$ 37$ bill & $\$ 35$ bill & Pos \\
\hline Remittances & $\begin{array}{ll}888 & \text { mill } \\
\text { pm } & \\
\end{array}$ & $\begin{array}{ll}\$ 350 \quad \text { mill } \\
\text { pm }\end{array}$ & Pos \\
\hline Exports & $\$ 7.8$ bill & $\$ 11.1$ bill & Pos \\
\hline Tax Revenue & $\begin{array}{ll}\text { PRs } & 391 \\
\text { bill } & \\
\end{array}$ & PRs 460 bill & Pos \\
\hline $\begin{array}{l}\text { Rupee-Dollar } \\
\text { Parity }\end{array}$ & Depr & $\begin{array}{l}\text { Appreciatin } \\
\mathrm{g}\end{array}$ & Pos \\
\hline $\begin{array}{l}\text { Foreign Direct } \\
\text { Inv. }\end{array}$ & \$472 mill & $\$ 800$ mill & Pos \\
\hline $\begin{array}{ll}\text { Foreign } & \text { Ex. } \\
\text { Res. } & \\
\end{array}$ & $\$ 1.6$ bill & $\$ 9.9$ bill & Pos \\
\hline $\begin{array}{l}\text { Poverty } \\
\text { Incidence }\end{array}$ & $33 \%$ & Rising & Neg \\
\hline $\begin{array}{ll}\text { Poverty } & \text { Rel. } \\
\text { Exp. } & \\
\end{array}$ & $\begin{array}{ll}\text { PRs } & 133 \\
\text { bill } & \\
\end{array}$ & PRs 161 bill & Pos \\
\hline Unemployment & $6 \%$ & $8 \%$ & Neg \\
\hline
\end{tabular}

In another study, Dr. Ishrat Husain (former Governor State Bank of Pakistan) studied ten macroeconomic indicators to judge the performance of economy by comparing the change from 1999 to 2001[4]. 
The findings of the study are summarized below:

Dr. Husain discusses the recent turnaround in Pakistan's economy and analyzes two different points of view about the Pakistan economy. One opinion regarding the present progress is that it is a mirage and a false dawn and that the economic structure has not changed much. The other point of view is that the change is the result of military government's sound policies during the Musharraf's regime and it will significantly change the economic landscape of the country over time.

TABLE 2: Macroeconomic Indicators before

Sep. 11, 2001

Source: SBP Annual Reports

\begin{tabular}{|l|l|l|}
\hline Indicators & FY 98-99 & $\begin{array}{l}\text { FY 00- } \\
\mathbf{0 1}\end{array}$ \\
\hline LSM growth rate (\%) & 3.6 & 11.0 \\
\hline Inflation rate & 5.7 & 4.4 \\
\hline Exports \% of GDP foreign exchange & $\begin{array}{l}7.8 \\
12.8\end{array}$ & $\begin{array}{l}9.2 \\
15.0\end{array}$ \\
\hline $\begin{array}{l}\text { Liquid } \\
\text { reserves } \\
\text { (\$ million) End-of-the-period }\end{array}$ & 1730 & 3212 \\
\hline $\begin{array}{l}\text { Budgetary Deficit (as of } \\
\text { GDP) }\end{array}$ & 6.1 & 5.3 \\
\hline CAB(as \% of GDP) & -3.8 & 0.6 \\
\hline Debt Servicing paid (\$ million) & 2657 & 8857 \\
\hline Tax revenues (Rs billion) & 308 & 392 \\
\hline $\begin{array}{l}\text { Ext Debt/Foreign Exc } \\
\text { Earnings }\end{array}$ & 335 & 259 \\
\hline $\begin{array}{l}\text { Public Debt Servicing /Public } \\
\text { Rev. }\end{array}$ & 64 & 57 \\
\hline
\end{tabular}

The World Bank, IMF, and ADB have published many reports that have highlighted the improved economic performance of Pakistan in the last three years but with caution. Recently, Dr. Ashfaq Husain, Advisor to the Prime Minister for Finance, responded to an article [5] in 'The Nation' which criticized the present government's economic performance. Dr. Ashfaq highlighted only weak areas of the previous democratic governments and nominal gains of the present regime.

Dr. Ashfaq presents only the bright side of the picture in making the case without properly analyzing the changing realities in the geopolitical and geo-strategic situation that Pakistan now faces after 9/11.

Another article published in Newsweek analyzed the progress in Pakistan's economy as follows, "Pakistan in many ways became the most surprising economic success stories of the world. GDP growth rate $8.4 \%$, the world's second highest behind the China by boosting fiscal discipline, government transparency

Journal of Independent Studies and Research (JISR)

Volume 4, Number 2, July 2006 and accountability, the budget deficit cut from $8 \%$ to $4 \%$ by slashing spending, and interest rates. The government has instituted a sweeping privatization program that has won kudos from both domestic and foreign investors. State owned companies in numerous industries - banking, cement, fertilizer, utilities, have been sold off, as has a chunk of the state's inefficient telecom giant, PTCL. People have snapped-up credit cards, buying cars and other expensive products with easy credit bank loan. European Union lifted all sanctions, USA dispersed $\$ 600$ million grant to meet urgent debt payments and erase off $\$ 1.5$ billion in debt. The EU lifted the quota sanctions on Pakistan's export. The GDP growth rate was near to zero, the country was world's most sanctioned nation after Libya. The government was forced to borrow exorbitant short-term rates, burdening the country with a crushing $\$ 38$ billion debt. Still all is not rosy, Pakistan must modernize its creaky infrastructure, improve tax collection and normalize the relationship with India. Government critics the current boom is not benefiting the country's poorest citizens, the rich have become more rich since $9 / 11$, and the middle class is better off. The economy is dangerously overheating due to unsustainable consumer demand and easy credit to both industrialists and consumers. Critics argue that growth spawned inflation which hit a high of 11 percent one year ago and is running this year at $8.5 \%$ is a big reason the poor are not benefiting from the boom”[6].

Dr. Subhash Kapila observes "For the first time in Pakistan's history, the Pakistan Army finds itself in severe dozens insurgency operations against their own people and suffering dozens of casualties there from...Pakistan's six years of military rule under General Musharraf has been a heavy price to pay for a country which aspired to be the leader of the Islamic World [7]. Similarly, Akbar Zaidi writes in his book [8] "When in power, military regimes have not worked either to establish effective conditions for the return to civilian rule or to develop institutions that might make military usurpation unnecessary in the future. Rather they have focused on immunizing themselves against criticism and deflecting any popular challenges that might arise. More dangerously in an effort to ensure their survival and mitigate perception of their illegitimacy, military regimes have repeatedly undermined centrist social forces and political parties in Pakistan by encouraging radical political groups opposed to democracy. They have also deliberately preferred privileged partly-less local governments over central and provincial institutions because the former typically cannot threaten core military interests relating to security policy, national budgets, and economic organization.”

The annual report of SPDC 2004 analyzed four areas like fiscal management, investment and growth, employment and wages, and social development during 
four eras like 1973-77, 1978-88, 1989-99, and 20002003 [9]. During the first decade of Pakistan, the country managed the growth rate of GDP over $3 \%$. Very soon after independence, the government acknowledged the precarious nature of the base of Pakistan's economy and by given the urgent consideration, the growth rate of industry in Pakistan was amongst the most rapid in the world [10]. The extraordinary high rate of manufacturing growth in this era was principally due to two factors, (i) the abnormally low level of manufacturing activity that Pakistan had at the time of the partition relative to what one would expect from a country of Pakistan's size and income level; and (ii) government polices which ensured a very high rate of profit in manufacturing through high domestic protection [11].

As the Literature in this section illustrates, there are many publications commenting on Pakistan's economy. In addition there has been a lot of work done to study and analyze the overall economic performance of Pakistan, mostly qualitatively, using only descriptive statistics. The past studies predominantly compare one single year with another or sometimes even a set of years. The researcher has discovered that there is no study published so far to assess Pakistan's economic performance inductively which utilizes inferential statistical methods comparing group means of macroeconomic and social indicators for a set of years with a political economic outlook.

\section{FRAMEWORK OF ANALYSIS}

A quantitative statistical model is formulated using both descriptive and inferential statistical techniques. Descriptive statistics for 28 macroeconomic variables is first used to obtain the three measures of central tendency, such as the mean, median, and mode. These measures then help to visualize the shape of the curve of the data with respect to symmetry and flatness by calculating the skewness and kurtosis of the data. This initial step is essential as the fundamental assumption in utilizing inferential statistical methods requires that the data approximate the normal distribution curve.

The inferential statistical model then starts off with comparing the group means of two independent samples with equal variances utilizing the T-Test, otherwise known as the student test, individually for 28 macroeconomic and social variables. The F-Test is then used to validate the assumption for equal variances. After finding that there are several variables which have unequal variances, the T-Test is then repeated for all the variables assuming unequal variances. A table summarizing the outputs obtained from SPSS (Statistical Package for Social Science) for the T-Test is constructed. To further validate the T-Test and the probability value, one factor ANOVA was applied. All these tests were conducted at the .01

Journal of Independent Studies and Research (JISR) Volume 4, Number 2, July 2006 significance level thereby minimizing Type-1 error with a 99\% confidence level of measurement. Then each variable analyzed is discussed historically to give a more in-depth perspective and understanding of the economic history being studied where the key variables are summarized in the next section. In our model, the main hypothesis we investigate is whether the group means of two samples are equal. To construct and utilize this test, three assumptions are required:

(i) The sampled populations are normally or approximately normally distributed

(ii) The two populations are independent

(iii) The standard deviations of the two populations are equal [11]

The two sample variances must be pooled to form a single estimate of the unknown population variance. We get the test value $t$ by dividing the difference with the standard error of the difference. In essence; we compute a weighted mean of the two sample standard deviations and use this weighted estimate of the population standard deviation. To start off one assumes that the populations have equal standard deviations.

\section{FINDINGS AND DISCUSSION}

\subsection{Summary of Results}

Quantitative statistical tools were used to develop a multidimensional model in order to compare and find the statistical significance of the economic and social indicators in two different eras. To compare the economic and industrial performances of the two eras, democratic (1988-1999) and military (1999-2005), twenty eight (28) variables were selected. A summary of the results obtained from the model is shown in the following table:

TABLE 3: Summary of Analysis for T-Test and ANOVA

\begin{tabular}{|l|l|}
\hline $\begin{array}{l}\text { GROUP MEANS } \\
\text { EQUAL }\end{array}$ & $\begin{array}{l}\text { GROUP MEANS } \\
\text { UNEQUAL }\end{array}$ \\
\hline GDP & $\begin{array}{l}\text { Share of Industry as \% of } \\
\text { GDP }\end{array}$ \\
\hline Manufacturing & Savings \\
\hline LSM & $\begin{array}{l}\text { Defense Spending as \% of } \\
\text { GDP }\end{array}$ \\
\hline SSM & $\begin{array}{l}\text { Def. Spending as \% Current } \\
\text { Exp. }\end{array}$ \\
\hline Investment & Unemployment Rate \\
\hline Export Growth & Consumer Price Index \\
\hline Export as \% of GDP & Budget Deficit \\
\hline GDP Deflator & Current Account Balance \\
\hline Balance of Trade & Exchange Rate \\
\hline Currency Dep. & Debt as \% of GDP \\
\hline
\end{tabular}




\begin{tabular}{|l|l|}
\hline Invest. in Education & Foreign Reserve \\
\hline Invest. in Health & Poverty \\
\hline Per Capita Income & \\
\hline Debt Servicing & \\
\hline Interest Payment & \\
\hline Work Remittances & \\
\hline
\end{tabular}

\subsection{GDP}

The average growth rate of GDP during the 17 years $1989-2005$ being studied was $4.6 \%$. Incidentally, during the democratic era (FY89-FY99) the GDP growth rate averaged $4.6 \%$, while during military regime (FY00 -FY05) it increased slightly to $4.8 \%$. Even though there is no significant statistical difference between the two eras under study but there is large variation during the military regime (FY00-FY05). In the first three fiscal years of military regime (19992002) the GDP growth average was only $2.9 \%$, and it more than doubled during the next three years to $6.3 \%$, a 3.4\% jump in the growth rate of GDP.

Independent and objective political economists point to essentially three factors to explain the increase in the growth rate of GDP; first, the event of 9/11 which increased geopolitical importance of Pakistan in the international war on terrorism, secondly, the strict adherence of the Pakistani government to the International financial institutions reform agenda, and lastly, the re-basing exercise carried out by the government where the base year of measurement was changed from 1980-81 to 1999-2000[12].

As a result of re-basing GDP, estimates for 19992000 have improved from Rs. 2,952 billion to Rs. 3,529 billion showing an increase of $19.5 \%$ over the old base estimates. Estimates are: agriculture sector improved by $18.5 \%$, the industrial sector by $18 \%$ and the services sector by $21.9 \%$ over the old base. Per capita income has been estimated at US\$526 for the re-based year 1999-2000 compared to US\$441 on the basis of 198081 basis. Similarly, estimates of fixed investment have improved by $34.3 \%$ to Rs. 607 billion over $1980-81$ based estimates of Rs. 452 billion mainly due to improved coverage. Therefore, one can safely deduce that the 6.4\% GDP growth rate in FY04 and 8.4\% growth rate in FY05 are significantly overstated. Unfortunately, the Economic Survey does not provide the data for these two years based on the common base year 1980-81 which would be the right basis of comparison for all the relevant data being studied in this thesis.

The following bar graph presents the comparison.

Journal of Independent Studies and Research (JISR) Volume 4, Number 2, July 2006

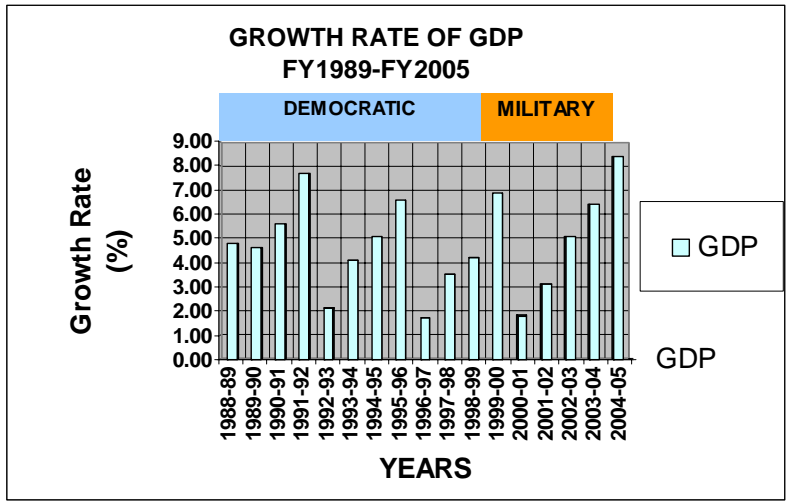

Source: Pakistan Economic Survey (various publications)

\subsection{Performance of Industrial Sector}

The average growth rate of manufacturing was 6.2 during the 17 years of both regimes. The key finding of this study is that there is no statistical difference in the group means and growth rate of manufacturing, LSM \& SSM, and total investment during the two different time periods. The manufacturing growth rate was very volatile during the democratic era; it was highest $8.05 \%$ in the FY92, and the lowest in FY97 at $1.29 \%$. The military era enjoys the higher growth rate of $9.19 \%$ almost three times than the democratic era of $3.4 \%$. The average growth rate of small scale manufacturing (SSM) was 7.26\% during the last 17 years (1989-2005). The growth rate of SSM during the democratic era was $7.84 \%$ and it reduced to $6.20 \%$ during the military regime indicating the disregard for this sector. The growth rate was relatively constant at $8.40 \%$ during the first nine years of democratic regime but in the last two years it decreased to $5.31 \%$. The growth rate of SSM varied from $4.50 \%$ low to $7.50 \%$ high during the military regime-not a very impressive performance.

\subsection{Investment and Savings}

Total investment as \% of GDP during (1989-2005) was $17.63 \%$. During democratic era it was $17.93 \%$, while in military it dropped to $17.07 \%$. The t-Test and ANOVA test results show that there is no statistical difference between the two eras. The share of industry as $\%$ of GDP was relatively constant at $24.85 \%$ of GDP during both the regimes. It was slightly higher at $25.59 \%$ in democratic and dropped to $23.5 \%$ in the military eras mainly due to the increase in the share of the services sector which increased to 52\% of GDP. Over all, there was little variation in both the regimes.

The investment as a proportion of GDP was highest in FY1993 at 20.70\% and lowest at 11.34\% in FY1990 in democratic era, while it was between 16\% and $17 \%$ in Musharraf regime. Savings as a percent of GDP averaged $15.16 \%$ during the last seventeen years (1989-2005). It averaged higher during the military 
regime at $17.67 \%$ and averaged lower at $13.79 \%$ during the democratic era. It was $20.80 \%$ very high in 2002-03 mainly due to the changes in the world after $9 / 11$, and overseas Pakistanis saved their money in Pakistan. The following graphs present the same.

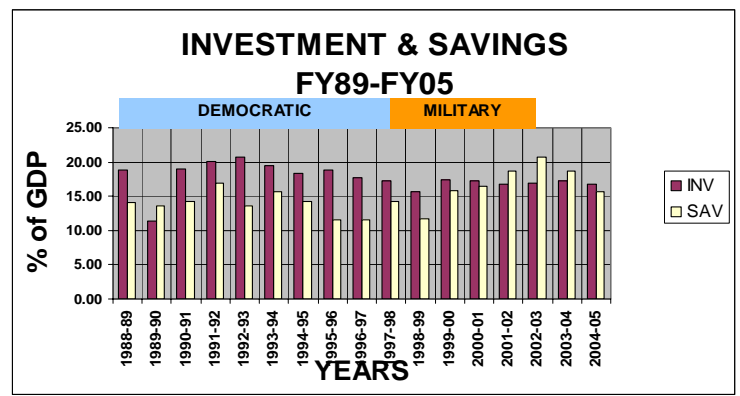

Source: Pakistan Economic Survey (various publications)

\subsection{Defense Spending}

Although defense spending has been increasing every year, the statistics show that defense spending as a percentage of current expenditure as well as a percentage of GDP has been actually declining. The average defense spending as percent of current expenditure during (1989-2005) was 22.25\%. It was highest at 26.5\% in FY90 during the democratic era and lowest during the military regime at $18.5 \%$ in FY05. This study shows the significant statistical difference between the two eras. During the democratic era the Defense spending as \% of GDP was generally higher than the military regime. In FY90 it reached a high of $6.9 \%$ of GDP while in FY01 it bottomed out at 3.7\% of GDP. The defense spending during 1989-2005 averaged $5.27 \%$ of GDP. It averaged $5.87 \%$ during the democratic era and $4.4 \%$ during the military regime respectively. The main reason for the reduction in defense spending as a proportion of current expenditure and as a percent of GDP is due to 'creative accounting'. Several items which are part of defense spending such as the salary and pensions of many active and retired armed forces personnel are included in the civilian budget. Besides the re-designing of budget, the good bilateral relationship with India is also a reason in the reduction of defense spending.

\subsection{Unemployment And Inflation}

There is significant statistical difference in the Unemployment Rate and Consumer Price Index in the two eras. The average unemployment rate during (1989-2005) was close to 6\%. During the democratic era it averaged $5.19 \%$ and increased to $7.52 \%$ during the military era. Despite high growth rate like $8.4 \%$ in 2004-05, and 6.40\% in 2003-04, the unemployment rate has increased which shows that the benefit of high growth rate of GDP is not benefiting the masses. The unemployment rate reached a low of 3.13\% in FY90 during Benazir Bhutto's government and a high of $6.22 \%$ in the following year FY91 which was in Mian Nawaz Sharif's tenure. During the military era it touched the highest ever at $8.70 \%$ in FY05.

The average inflation rate when measured by the consumer price index was $8.14 \%$ during the last 17 years and $8.60 \%$ when measured using the GDP deflator. It averaged close to $10 \%$ during the democratic era and $4.75 \%$ in the military regime. During the democratic era it ranged within $5.70 \%$ to $13 \%$. There is also high variation during the military regime as the CPI was $3.10 \%$ in FY03 and $9.30 \%$ in FY05. The average growth rate of GDP deflator was $8.60 \%$ during the 17 year period. The average growth rate of GDP deflator was $10.09 \%$ in the democratic era much higher than during the military regime at 5.89\%. The graphical presentation of the same is as under:

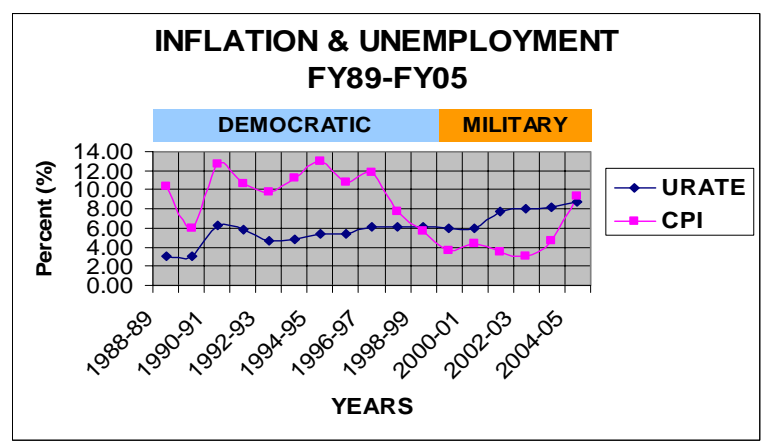

Source: Pakistan Economic Survey (various publications)

\subsection{Budget Deficit and Current Account Balance}

The budget deficit averaged 5.89\% of GDP during the last seventeen years. It averaged close to $7 \%$ in the democratic era which is much greater than $3.95 \%$ in the military regime. There is large variation during the democratic era, it fluctuated between $5.6 \%$ and $8.8 \%$ during this era. During the military era, it was better contained within $3 \%$ to $4.3 \%$ of GDP.

The average balance in the current account was $2.72 \%$ of GDP during the last 17 years. In the democratic era, the current account was in deficit and averaged $-4.8 \%$ of GDP but was in surplus in the military regime at $0.53 \%$ of GDP. During the entire democratic era, the deficit ranged from $-2.80 \%$ to $7.20 \%$. This deficit was converted into positive balance during the military era as it substantially narrowed down from $-1.60 \%$ in FY00 to $3.8 \%$ in FY03, mainly due to Pakistan's favorable position after 9/11 when it was reconnected to the international financial system. 


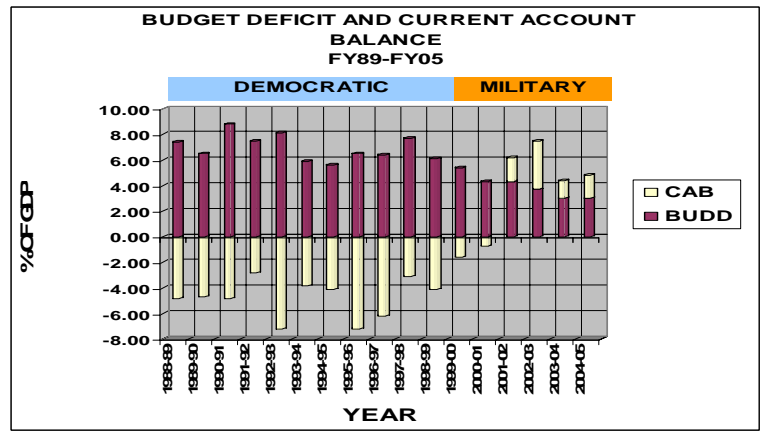

Source: Pakistan Economic Survey (various publications)

\subsection{Trade}

The average exports as \% of GDP was $12.92 \%$ during 1989-2005. It was almost exactly the same during the military regime at $12.95 \%$ and the democratic era at $12.91 \%$. Export growth averaged $11.38 \%$ during the military era and $5.45 \%$ during the democratic era. There is a high variation in export growth during the entire period particularly in democratic era where it reached a high of $19.80 \%$ in 1990-91, and a low of $-10.70 \%$ in $1998-99$ yielding a variation of almost 30\%. During the military regime it was $2.30 \%$ low in FY02 but it was $19.10 \%$ very high in the subsequent year.

\subsubsection{Workers Remittances}

The average worker remittances as \% of GDP was $3.15 \%$ during the last seventeen years; during the democratic era it was $3.13 \%$ and in military era it was $3.21 \%$. So essentially there is no difference in the workers remittances as a proportion of GDP during the two regimes. Worker Remittances were higher at $4.90 \%$ in FY90 and narrowed to $1.30 \%$ in FY99.

\subsubsection{Foreign Exchange Reserves}

Robust foreign exchange reserves position reduced vulnerability of the exchange rate and provided some stability to country's currency value. However, on domestic front, despite structural adjustments, economic growth rate remained stagnant until 2003 mainly due to neglect of overall investment especially in the social sector, infrastructure and human development.

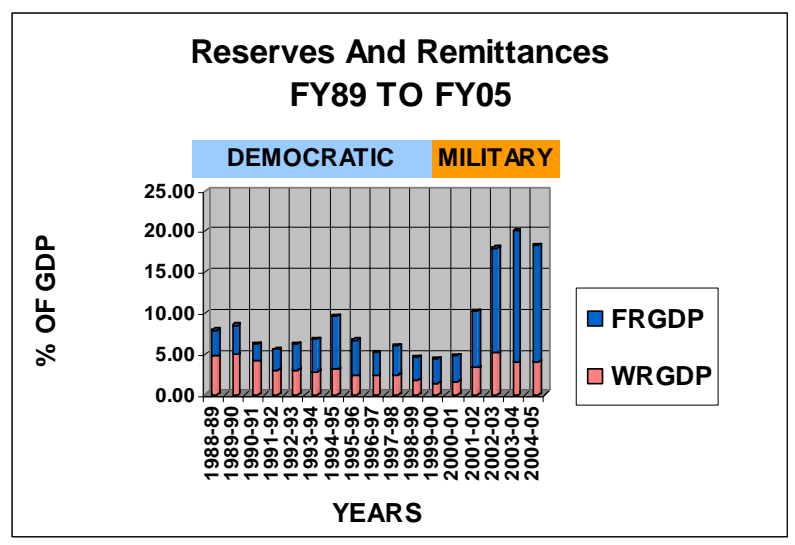

Source: Pakistan Economic Survey (various publications)

\subsection{Social Sectors}

\subsubsection{Education}

The average growth rate of Investment in education as \% of GDP was 2.18 during the entire period of study. The investment in education was $2.28 \%$ which was slightly higher during democratic era than the military era of $2.0 \%$. This important area was equally neglected in both the eras. During the democratic era it was almost constant. The minimum 2.10 in 1991-92, and the 2.50 is the maximum in 199697. The minimum and maximum of military rulers were 1.60 and 2.50 in 2000-01, and 2004-05 respectively. There is no statistical difference in both the eras.

\subsubsection{Health}

The average growth rate of Investment in health sector during the 17 years of study (1989-2005) was $.7118 \%$.

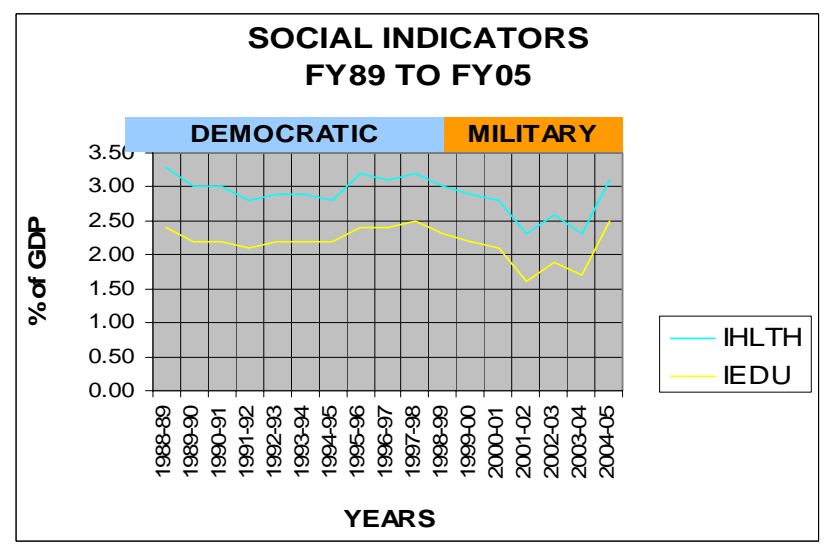

Source: Pakistan Economic Survey (various publications) 
During the democratic era it was 0.74 , while during military era it was $0.67 \%$. It shows that there is no significant statistical difference between the two eras

\subsubsection{Poverty}

During the period of study (1989-2005) the average growth of poverty in Pakistan is $30.13 \%$. There is statistical difference in both regimes. The average growth was $31.7 \%$ in military era and $29 \%$ during the democratic regime. The definition of poverty differs from country to country. The level of Poverty is defined by the government of Pakistan by the benchmark of rupee value of Rs. 25 a day or Rs. 748 a month enough to afford 2,350 calories a day. Anyone earning less than this is considered as absolute poor. Many economists estimate that in order to make an impact on poverty, GDP growth rate should be sustained at least $6 \%$. In order for Pakistan to have that kind of rate, during the next 6 years, GDP would have to average at least $7.2 \%$.

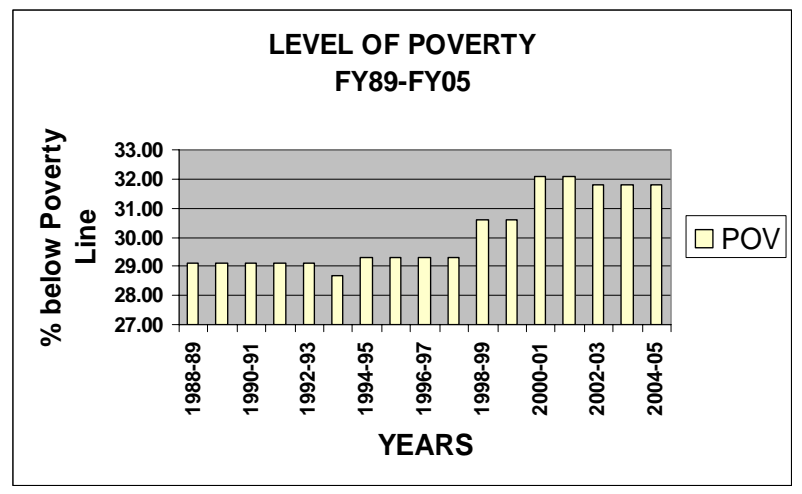

Source: Pakistan Economic Survey (various publications)

\section{CONCLUSIONS}

This paper was an attempt to assess whether the current military regime performed better than the previous democratic regime as indicated by key economic and social indicators published by the government. Inferential statistics was used over a period of time 1989-2005 to analyze the difference in group means of the time period as opposed to comparing them from one year to another which is the conventional method. The findings indicate that amongst the key macroeconomic variables there is no significant difference in the group means for most of the variables studied. Therefore, the main conclusion of this study is that the current military regime has not performed significantly better than the previous regimes in the democratic era as indicated by key economic and social indicators. The overall quality of life in terms of the development of the social sectors (i.e., education, health, and poverty) has also not improved significantly during the present military rule as compared to the previous democratic era. In fact, it has remained stagnant or even worsened. Journal of Independent Studies and Research (JISR) Volume 4, Number 2, July 2006

\section{REFERENCES}

[1] Various publications Pakistan Economic Surveys. Govt. of Pakistan, Finance Division, Economic Adviser's Wing, Islamabad

[2] Pakistan Economic Survey 2004-05 Govt. of Pakistan, Finance Division, Economic Adviser's Wing, Islamabad

[3] Faisal Cheema, 2004, 'Macro economic stability of Pakistan 1997-2003' University of Illinois-Champaign, ACDIS Occasional paper http://www.acdis.uiuc.edu/Research/OPs/Chee ma/contents/part1.html

[4] Dr. Ishrat Husain, Oct. 2004, “Pakistan's economic progress since 2000: False Dawn or a Promising Start” paper presented at John Hopkins, University of Washington DC

[5] 'Economic Achievements: First Year of Prime Minister Shaukat Aziz's Government', Dr. Ashfaque Hasan Khan, Govt. of Pakistan, Finance Division, Economic Adviser's Wing, Islamabad

http://www.finance.gov.pk/articles/1YearProfe rmence.pdf

[6] Ron Moreau, March 27, 2006, article, “Promise in Pakistan” page 32, Newsweek

Dr. Subhash Kapila, 'Pakistan's Six years of Military Rule Reviewed' Daily The Nation, 18-10-2005South Asia Analysis Group

[8] Zaidi S. Akber, 2005, 'Issues in Pakistan’s Economy’, 2005, Oxford University Press, Karachi

[9] Annual Report 2004, SPDC, Page no. 10

[10] Zaidi S. Akber, 1999, 'Issues in Pakistan’s Economy’ Oxford, page 85

[11] Mason D. Robert, 1999, 'Statistical Techniques in Business \& Economics' $10^{\text {th }}$ edition, Irwin/McGrar-Hill, Page no. 363-4

[12] Pakistan Economic Survey 2003-04 Govt. of Pakistan, Finance Division, Economic Adviser's Wing, Islamabad

[13] Pervez Hasan, 1998, 'Pakistan's economy at the Crossroads: Past Polices and Present Imperatives' Oxford, pg. no 54 